tients with severe alcoholic hepatitis. Clin Gastroenterol Hepatol 2018;16(10):1650-1656.e2.

4. Garg V, Garg H, Khan A, et al. Granulocyte colony-stimulating factor mobilizes CD34(+) cells and improves survival of patients with acute-on-chronic liver failure. Gastroenterology 2012; 142(3):505-512.e1.

DOI: $10.1056 /$ NEJMc1814129

THE AUTHORS REPLY: Caputo and colleagues agree with us that short-acting benzodiazepines are the cornerstone for treating patients with the alcohol withdrawal syndrome. They suggest that we ought to have included sodium oxybate (the sodium salt of $\gamma$-hydroxybutyric acid [GHB]) among the alternative therapies. Sodium oxybate is approved for the treatment of the alcohol withdrawal syndrome in Italy and Austria and for the treatment of narcolepsy in the United States. ${ }^{1}$ In addition to space constraints, we did not include sodium oxybate among the potential alternative treatments, mainly because of its potential for abuse and its adverse-effect profile. ${ }^{2}$ In addition to the references cited by Caputo and colleagues, a recent article published after our manuscript went to press reported pooled data from 3436 patients with alcohol dependence and a pharmacovigilance database involving more than 260,000 patients with alcohol dependence who had been treated with sodium oxybate with very few adverse side effects and only a few cases of abuse. ${ }^{1}$ In a review article published 20 years ago in the Journal, another Italian researcher argued for the inclusion of $\mathrm{GHB}$ as a potential treatment for the alcohol withdrawal syndrome and for relapse prevention. ${ }^{3}$ We believe that benzodiazepines are the drug of choice and that sodium oxybate could be considered, at best, as an option for treatment when other established medications are not appropriate.

Rathi and colleagues share their perspective on the treatment of alcoholic hepatitis. This is a matter that we did not discuss in our article because we believed it was beyond its scope. We agree with Rathi and colleagues that there is a need for exploration of new therapies beyond glucocorticoids and pentoxifylline, given that, as we noted in our article, patients with alcoholic hepatitis have a poor prognosis and very few patients will eventually benefit from liver transplantation.

Daniel Fuster, M.D., Ph.D.

Universitat Autonoma de Barcelona Badalona, Spain

Jeffrey H. Samet, M.D., M.P.H.

Boston University School of Medicine

Boston, MA

jsamet@bu.edu

Since publication of their article, the authors report no further potential conflict of interest.

1. van den Brink W, Addolorato G, Aubin H-J, et al. Efficacy and safety of sodium oxybate in alcohol-dependent patients with a very high drinking risk level. Addict Biol 2018;23:969-86.

2. Lee MR, Leggio L. Management of alcohol use disorder in patients requiring liver transplant. Am J Psychiatry 2015;172: 1182-9.

3. Addolorato G, Stefanini GF, Gasbarrini G. Patients with alcohol problems. N Engl J Med 1998;339:130-1.

DOI: $10.1056 / N E J M c 1814129$

\title{
Antibody-Mediated Rejection of Solid-Organ Allografts
}

TO THE EDITOR: The comprehensive review article by Loupy and Lefaucheur (Sept. 20 issue) $)^{1}$ on antibody-mediated rejection describes major advances in understanding the pathophysiological process and diagnosis of antibody-mediated rejection, but successful treatment is still limited to the acute forms of antibody-mediated rejection. ${ }^{2}$ Allograft loss eventually occurs in the majority of patients in whom true pathogenic donorspecific anti-HLA antibodies develop. ${ }^{3}$ This is frustrating for both clinicians and patients because even treatments administered at early stages of the disease are not effective. It is quite obvious that the best strategy to minimize the risk of donor-specific antibodies is to improve the level of HLA matching between the donor and recipient. ${ }^{4}$ This point was omitted in the article.

Recent studies suggest that molecular HLA eplet matching could reduce the risk of the development of donor-specific antibodies. ${ }^{5}$ Since class II rather than class I donor-specific antibodies are associated with chronic antibody-mediated rejection, this strategy to achieve HLA class II molecular matching appears to be feasible. The 
challenge is to find out how to integrate such a strategy into the current algorithms for solidorgan allocation.

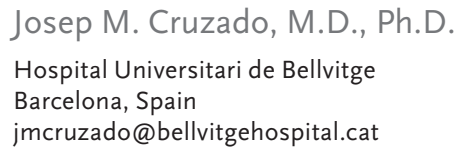

No potential conflict of interest relevant to this letter was reported.

1. Loupy A, Lefaucheur C. Antibody-mediated rejection of solidorgan allografts. N Engl J Med 2018;379:1150-60.

2. Cruzado JM, Bestard O, Grinyó JM. Control of anti-donor antibody production post-transplantation: conventional and novel immunosuppressive therapies. Contrib Nephrol 2009;162: 117-28.

3. Sellarés J, de Freitas DG, Mengel M, et al. Understanding the causes of kidney transplant failure: the dominant role of antibody-mediated rejection and nonadherence. Am J Transplant 2012;12:388-99.

4. Williams RC, Opelz G, McGarvey CJ, Weil EJ, Chakkera HA. The risk of transplant failure with HLA mismatch in first adult kidney allografts from deceased donors. Transplantation 2016; 100:1094-102.

5. Wiebe C, Nickerson P. Human leukocyte antigen mismatch and precision medicine in transplantation. Curr Opin Organ Transplant 2018;23:500-5.

DOI: 10.1056/NEJMc1813976

TO THE EDITOR: In the review article by Loupy and Lefaucheur, the assertion that antibodies are a major cause of acute and chronic rejection of solid-organ allografts is not substantiated. Aside from rare cases of hyperacute or accelerated rejection in HLA-sensitized patients, ${ }^{1}$ a causal relationship between antibodies and rejection has not been established.

"Antibody-mediated rejection," as described by Loupy and Lefaucheur, occurs more commonly in association with or after cellular rejection than in isolation. ${ }^{2}$ It is frequently diagnosed in the absence of circulating donor-specific antiHLA antibodies or evidence of antibody binding to graft tissue. The histologic criteria used to infer the presence of antibodies, including $\mathrm{C} 4 \mathrm{~d}$, are not specific. In a study of heart transplantation, even when antibody binding was detected histologically, it was associated with graft dysfunction in fewer than $5 \%$ of patients. ${ }^{3}$ Antibody-targeting therapies do not reverse "antibodymediated rejection," and in anecdotal cases in which improvement was observed, the effect of therapy on nonhumoral immunity could not be ruled out. Finally, in studies in animals, the absence of antibodies has not been shown to prevent lesions associated with "antibody-mediated rejection." ${ }^{4}$ Therefore, the term "antibodymediated rejection" should be used with caution until scientific causation is established. Mislabeling could misguide scientific investigations and trigger unwarranted interventions.



No potential conflict of interest relevant to this letter was reported.

1. Williams GM, Hume DM, Hudson RP Jr, Morris PJ, Kano K, Milgrom F. "Hyperacute" renal-homograft rejection in man. N Engl J Med 1968;279:611-8.

2. Wiebe C, Gibson IW, Blydt-Hansen TD, et al. Rates and determinants of progression to graft failure in kidney allograft recipients with de novo donor-specific antibody. Am J Transplant 2015;15:2921-30.

3. Rodriguez ER, Skojec DV, Tan CD, et al. Antibody-mediated rejection in human cardiac allografts: evaluation of immunoglobulins and complement activation products C4d and C3d as markers. Am J Transplant 2005;5:2778-85.

4. Zeng Q, Ng YH, Singh T, et al. B cells mediate chronic allograft rejection independently of antibody production. J Clin Invest 2014;124:1052-6.

DOI: $10.1056 /$ NEJMc1813976

THE AUTHORS REPLY: In reply to Cruzado: our review article focused on recent insights regarding the diagnosis and clinical presentation of antibody-mediated rejection and the resulting clinically actionable biomarkers for monitoring and therapeutic follow-up of patients who receive transplants. The potential for new allocation policies aimed at reducing the incidence of allograft rejection, including HLA matching at the eplet level, is an interesting but complex subject that would require a dedicated overall review to be fully addressed. Moreover, the feasibility of such precise HLA matching in the time-sensitive, real-world setting of current allocation logistics remains to be developed.

We strongly disagree with the comments by Lakkis et al., since antibody-mediated rejection exists as a clinical entity primarily caused by circulating donor-specific anti-HLA antibodies. Although anti-HLA antibodies have been linked to a spectrum of pathogenicity, robust data from numerous clinical and basic studies published in the past three decades provide support for the 


\begin{tabular}{|c|c|}
\hline Criterion & Evidence \\
\hline $\begin{array}{l}\text { Strength of effect size } \\
\text { and reproducibility }\end{array}$ & $\begin{array}{l}\text { Strength of association and independence of effect have been reproduced with consis- } \\
\text { tency in studies, including large meta-analyses. }\end{array}$ \\
\hline Specificity & $\begin{array}{l}\text { Complement-dependent cross-matching that avoids cytotoxic donor-specific anti-HLA } \\
\text { antibodies has dramatically reduced the occurrence of acute antibody-mediated re- } \\
\text { jection and nearly eliminated hyperacute rejection. } \\
\text { Capillary deposition of complement fraction C } 4 \text { d has a high specificity for antibody ac- } \\
\text { tivation of complement. } \\
\text { Donor-specific anti-HLA antibodies are associated with basement-membrane injuries in } \\
\text { peritubular and glomerular capillaries that are lesions of chronic humoral rejection. }\end{array}$ \\
\hline Experimental evidence & $\begin{array}{l}\text { Donor-specific anti-HLA antibodies have been detected in tissue eluates from rejected } \\
\text { kidneys. } \\
\text { Passive transfer of complement-activating antibodies causes C4d deposition and anti- } \\
\text { body-mediated rejection. } \\
\text { Passive transfer of non-complement-activating antibodies does not cause C4d deposi- } \\
\text { tion and antibody-mediated rejection. } \\
\text { Models in animals show that donor-specific anti-HLA antibodies mediate allograft vas- } \\
\text { cular lesions with natural killer cells if T cells are lacking. }\end{array}$ \\
\hline Temporality & $\begin{array}{l}\text { Preexisting donor-specific anti-HLA antibodies correlate with the occurrence of antibody- } \\
\text { mediated rejection soon after transplantation. } \\
\text { The appearance of new-onset donor-specific anti-HLA antibodies precedes acute and } \\
\text { chronic antibody-mediated rejection. } \\
\text { Studies involving cynomolgus monkeys have shown the sequence from donor-specific } \\
\text { anti-HLA antibodies to acute and chronic antibody-mediated rejection. }\end{array}$ \\
\hline Biologic gradient & $\begin{array}{l}\text { Complement-activating donor-specific anti-HLA antibodies ( } \mathrm{Clq}, \mathrm{C} 3 \mathrm{~d}, \mathrm{C} 4 \mathrm{~d} \text {, and IgG3 } \\
\text { subclass) correlate with antibody-mediated rejection, disease activity, and outcome. } \\
\text { Models in animals have shown that antibody-mediated rejection is reproducibly induced } \\
\text { by passive transfer of complement-activating donor-specific anti-HLA antibodies } \\
\text { with a dose-dependent effect. }\end{array}$ \\
\hline Coherence and analogy & $\begin{array}{l}\text { Similar associations between donor-specific anti-HLA antibodies and antibody-mediated } \\
\text { rejection have been shown in kidney, lung, heart, and pancreas composite tissue } \\
\text { transplantation and liver transplantation. }\end{array}$ \\
\hline
\end{tabular}

causality of anti-HLA antibodies in antibodymediated rejection. ${ }^{1}$ Many criteria for evidence of causation as applied to antibody-mediated rejection have been met, including the strength of the effect size, consistency and reproducibility, specificity, a strong biologic gradient, a dose-dependent effect, additional biologic plausibility, and experimental models in animals that indicate causation (Table 1). ${ }^{2}$

In our review article, the definition of antibody-mediated rejection in kidney, lung, heart, liver, and pancreas transplantation was consistent with that used by the Banff classification of kidney allograft rejection and the classification of the International Society for Heart and Lung Transplantation. Beyond providing a standardized nomenclature, these classifications base the diagnosis of antibody-mediated rejection on a combination of several markers (antibodies, path- ological and immunochemical features, and gene expression) that are directly derived from the evidence described above. Regarding the comment on antibody-negative antibody-mediated rejection, these phenotypes are far less frequent in clinical practice than those related to HLA antibodies ${ }^{3}$ and do not rule out the presence of other non-HLA pathogenic antibodies. ${ }^{4}$ Finally, the experience of clinicians who treat patients with antibody-mediated rejection as well as results published in the recent literature are not in line with the assertion by Lakkis and colleagues regarding an "anecdotal" efficacy of antibody-targeting therapies. These findings indicate that more than two thirds of patients with active antibody-mediated rejection after kidney transplantation have had a response to antibody-targeting treatment leading to allograft survival. ${ }^{3,5}$ 
Carmen Lefaucheur, M.D., Ph.D.

Alexandre Loupy, M.D., Ph.D.

Paris Translational Research Center for Organ Transplantation Paris, France

alexandre.loupy@inserm.fr

Since publication of their article, the authors report no further potential conflict of interest.

1. Cai J, Terasaki PI. Humoral theory of transplantation: mechanism, prevention, and treatment. Hum Immunol 2005;66:334-42. 2. Akiyoshi $\mathrm{T}$, Hirohashi $\mathrm{T}$, Alessandrini $\mathrm{A}$, et al. Role of complement and NK cells in antibody mediated rejection. Hum Immunol 2012;73:1226-32.

3. Montgomery RA, Loupy A, Segev DL. Antibody-mediated rejection: new approaches in prevention and management. Am J Transplant 2018;18:Suppl 3:3-17.

4. Dragun D, Müller DN, Bräsen JH, et al. Angiotensin II type 1receptor activating antibodies in renal-allograft rejection. $\mathrm{N}$ Engl J Med 2005;352:558-69.

5. Viglietti D, Loupy A, Aubert O, et al. Dynamic prognostic score to predict kidney allograft survival in patients with antibody-mediated rejection. J Am Soc Nephrol 2018;29:606-19.

DOI: 10.1056/NEJMc1813976

Correspondence Copyright @ 2018 Massachusetts Medical Society.

\section{INSTRUCTIONS FOR LETTERS TO THE EDITOR}

Letters to the Editor are considered for publication, subject to editing and abridgment, provided they do not contain material that has been submitted or published elsewhere.

Letters accepted for publication will appear in print, on our website at NEJM.org, or both.

Please note the following:

- Letters in reference to a Journal article must not exceed 175 words (excluding references) and must be received within 3 weeks after publication of the article.

- Letters not related to a Journal article must not exceed 400 words.

- A letter can have no more than five references and one figure or table.

- A letter can be signed by no more than three authors.

- Financial associations or other possible conflicts of interest must be disclosed. Disclosures will be published with the letters. (For authors of Journal articles who are responding to letters, we will only publish new relevant relationships that have developed since publication of the article.)

- Include your full mailing address, telephone number, fax number, and email address with your letter.

- All letters must be submitted through our online submission system at NEJM.org.

Letters that do not adhere to these instructions will not be considered. We will notify you when we have made a decision about possible publication. Letters regarding a recent Journal article may be shared with the authors of that article. We are unable to provide prepublication proofs. Submission of a letter constitutes permission for the Massachusetts Medical Society, its licensees, and its assignees to use it in the Journal's various print and electronic publications and in collections, revisions, and any other form or medium.

\section{CORRECTION}

Ribociclib as First-Line Therapy for HR-Positive, Advanced Breast Cancer (N Engl J Med 2016;375:1738-1748). The disclosure statement (page 1747) has been updated to include disclosures for Drs. Howard A. Burris, Carlos L. Arteaga, and Denise Yardley. The disclosure forms have also been updated. The article is correct at NEJM.org.

\section{NOTICES}

Notices submitted for publication should contain a mailing address and telephone number of a contact person or department. We regret that we are unable to publish all notices received.

\section{CALL FOR ABSTRACTS}

The European Academy of Paediatrics is accepting abstracts for its "EAP 2019 Congress and MasterCourse," to be held in Porto, Portugal, Sept. 19-22. Deadline for submission is Feb. 20.

Contact Paragon Group, 18 Avenue Louis-Casai, 1209 Geneva, Switzerland; or call +41 (0) 225330 948; or fax +41 (0) 22 5802 953; or e-mail congress@eapaediatrics.eu; or see http:// www.eapcongress.com/abstract-submission.

\section{STEM CELLS \& ORGANOIDS IN DEVELOPMENT \\ \& DISEASE}

The symposium will be held in Amsterdam, Feb. 20-22.

Contact the International Society for Stem Cell Research, 5215 Old Orchard Rd., Suite 270, Skokie, IL 60077; or call (224) 592-5700; or see http://www.isscr.org.

\section{THOMAS L. PETTY ASPEN LUNG CONFERENCE}

The 62nd Annual Meeting, entitled "Exploring New Therapeutic Pathways in Pulmonary Hypertension: Metabolism, Proliferation, and Personalized Medicine," will be held in Aspen, CO, June 5-8. Deadline for submission of abstracts is Feb. 14.

Contact Dr. Brian Graham, c/o Jeanne Cleary, Thomas L. Petty Aspen Lung Conference, P.O. Box 1622, Parker, CO 80134; or call (303) 358-2797; or e-mail Jeanne.Cleary@ucdenver.edu; or see http://www.aspenlungconference.org.

\section{MAYO CLINIC SCOTTSDALE}

The following courses will be offered in Scottsdale, AZ, unless otherwise indicated: "Mayo Pathology Update 2019" (Phoenix, AZ, Jan. 24-26); "Practical Proton Therapy Seminar and Workshop" (Jan. 24-26); and "15th Annual Mayo Clinic Women's Health Update" (Feb. 28-March 2).

Contact Mayo School of Continuous Professional Development, Mayo Clinic, 13400 E. Shea Blvd., Scottsdale, AZ 85259; or call (480) 301-4580; or fax (480) 301-8323; or e-mail mca.cme@mayo.edu; or see http://www.mayo.edu/cme.

THE JOURNAL'S WEB AND EMAIL ADDRESSES

To submit a letter to the Editor: authors.NEJM.org

For information about the status of a submitted manuscript: authors.NEJM.org

To submit a meeting notice: meetingnotices@NEJM.org The Journal's web pages: NEJM.org 